\title{
Differentiation of concentration level of iron compounds in water reservoirs in subsidence depressions in the Katowice Upland
}

\author{
Robert Machowski \\ University of Silesia, Faculty of Earth Sciences, Department of Physical Geography, Będzińska 60, 41-200 Sosnowiec, Poland, \\ e-mail: robert.machowski@us.edu.pl
}

\begin{abstract}
The aim of investigations was to evaluate the influence of varied anthropopression on the concentration of iron compounds in water reservoirs located in subsidence depressions treated as geosystems. Investigations were carried out during period of three hydrological years 2003-2005 within 10 reservoirs located in the Katowice Upland. The presence of iron was systematically measured in water and one time in bottom deposits. Measurements in taken samples were made by means of spectrometer of atomic absorption SOLAAR M6. Results confirmed varied influence of anthropopression on concentration of iron compounds in described reservoirs. It refers to waters and bottom deposits as well. Large differences between reservoirs occurred in a case of iron concentration in bottom deposits. The smallest amounts of it $\left(3.10 \mathrm{~g} \mathrm{~kg}^{-1}\right)$ were stated in transfer (flow-through) reservoir in Sosnowiec. Maximum values occurred also in reservoir in Sosnowiec, and the level of iron concentration in its deposits amounted to $44.28 \mathrm{~g} \mathrm{~kg}^{-1}$. Waters were also characterized by varied level of iron concentration. The lowest average values $\left(0.0437 \mathrm{mg} \mathrm{Fe}^{-1}\right)$ were typical for one of reservoirs in

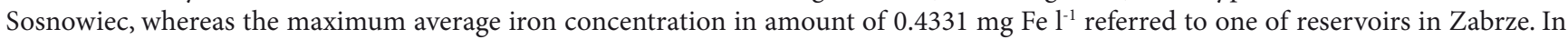
the described reservoirs dynamic temporal changes in iron concentration in limnic waters was also stated. In every reservoir periods of complete disappearance of this metal occurred, whereas the maximum amounts of it in particular objects changed from $0.1132 \mathrm{mg}$

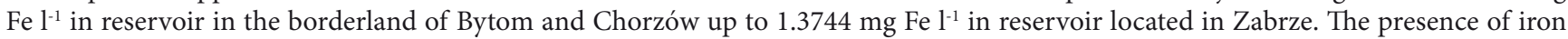
compounds in the described water reservoirs on the one hand is shaped by environmental conditions, but on the other hand varied influence of anthropopression decides significantly of their spatial and temporal cycle in the nature.
\end{abstract}

Key words: anthropopression, Katowice Upland, limnology, bottom deposits, iron

\section{Introduction}

The Katowice Upland is one of central mesoregions of the Silesian Upland (Fig. 1). On the scale of the whole country these terrains are characterized by the largest changes in the natural environment, caused by human economic activity. The location of area investigated in the watershed zone of the Vistula and Oder catchments and the kind of substratum deposits, mainly Triassic limestones and dolomites, influence on the poverty of surface water resources. Despite the disadvantageous environmental conditions in the area described some thousand artificial water reservoirs occur. They were originated in result of planned human undertakings (e.g. dam reservoirs), and they are unintentional effect of economic activation of the region (e.g. reservoirs in subsidence depressions) as well. The number of some thousand objects fulfilling retention functions, and the significant area, which they occupy, allows talking of these terrains for a rather long time as a specific „anthropogenic lakeland” (Jankowski 1986; Czaja 2003; Jankowski and Rzętała 2004; Machowski and Rzętała 2006; Machowski et al. 2006; Rzętała 2008).

The genesis of water reservoirs in subsidence basins in the area of the Katowice Upland is connected with underground exploitation of black coal and - to a smaller degree - zinc and lead ores as well. In result of extraction of above mentioned deposits of mineral resources under the terrain surface empty spaces originate. Rock masses, in connection with the development of vertical movements, slowly move towards the voids originated. The consequence of such type translocations are morphological changes appearing at the terrain surface in a form of strata reflection, ground subsiding and collapsing (Żmuda 1973). The depth, on 
which the mining works take part, is of deciding importance in the formation of subsidence basins or collapsed. In the case, when the exploitation is carried out at small depths, the violent movement of rocky masses happens, in result of which discontinuous deformations originate, such as: scarps, cones, fissures and ditches. Subsidence depressions, originating in result of continuous deformations, are connected with exploitation carried out at significant depths, which usually exceed 100 meters. In other cases rocks occurring above the working have to be characterized by large plasticity. The process of subsiding occurs in result of fall, fissuring and deflection in vertical and horizontal plane. Basin most often assumes the shape resembling the circle or ellipsis, and its size, range and process of origination depends on mining-geological factors. The predominating role on this question is played by the thickness of exploitation bed and the way of liquidation of originated veins. The largest terrain subsidence originates in result of full exploitation with roof fall, when the subsidence coefficient amounts to 0.7 per every meter of extracted bed, whereas the smallest deformations of terrain surface have the connection with partial exploitation, carried out by means of belts with hydraulic stowage and they are shaped at the level of 0.02-0.03 at the bed depth amounting to 1 meter (Szpetkowski 1980). Processes of terrain subsiding in the Silesian Upland are common phenomena occurring most of all in area of the Katowice Upland, but also in terrains of the Rybnik Plateau. They cause real economic losses called mining damage (Jankowski et al. 2001).

\section{Research aims and methods}

The essential aim of carried out investigations was to evaluate the influence of anthropopression on the concentration of iron compounds in water reservoirs in subsidence basins treated as geosystems. Analysed reservoirs are located in Sosnowiec, Zabrze and in the borderland of Bytom and Chorzów, at terrains, which are subject to subsiding. To research 10 small in area water reservoirs were selected (as the most representative for this genetic group), being under the varied influence of anthropopression (Fig. 1). Considering their small areas and no great depths

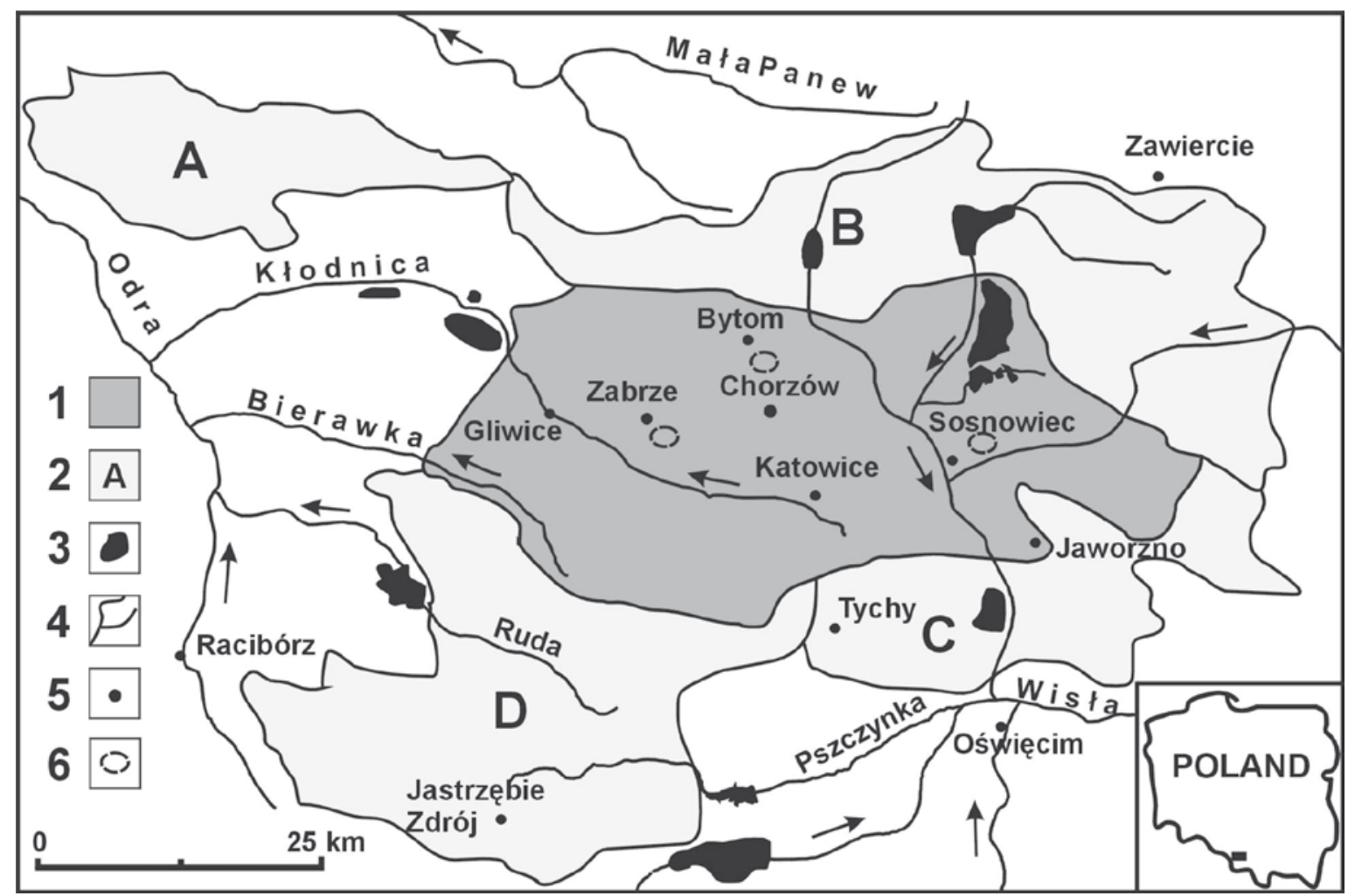

Fig. 1. Location of the study area. 1 - Katowice Upland; 2 - remaining mesoregions of the Silesian Upland: A - Chełm , B - Hummock of Tarnowskie Góry, C - Jaworzno Hills, D - Rybnik Plateau; 3 - more important water reservoirs, 4 - river network, 5 - more important towns, 6 - location of the research reservoirs 
samples were taken from the surface water layer one time in the month during the period of three hydrological years 2003-2005. Such often period of sampling is recommended among others by M. Świderska-Bróż (1993), who pays the attention to the fact, that metals relatively quickly migrate between the water environment and bottom deposits. Therefore the systematical and frequent measurements allow obtaining reliable results, which are necessary in research of such type. Samples were taken to chemically inert containers, made of high-pressure polyethylene of capacity of 125 $\mathrm{ml}$. They were filled by immersing after three-times rinsing out with water taken for analysis (Burchard et al. 1990). To conserve samples, waters were acidified by means of ultra pure nitric acid of concentration of $70 \%$. This effort (lowering of $\mathrm{pH}$ up to about 2) should protect precipitation of iron compounds from the aqueous solution. After transporting water samples to laboratory, to remove suspensions, the filtration was made with applying pressure pump and filter papers millipore of hole diameter $0.45 \mu \mathrm{m}$. Next, iron determinations were made on the spectrometer of atomic absorption SOLAAR M, which was produced by the English firm Unicam Atomic Absorption, according to methodology given among others by J. Dojlido and J. Zerbe (1997).

For every from reservoirs investigated 2-3 samples of bottom deposits, which cover floors of their bowls were taken, and next they were subject to laboratory analysis. To determine iron the taken samples were dried in room temperature and then grinded down in agate mortar (Migaszewski 1998). Measured out sample masses in the presence of acids $\mathrm{HF}, \mathrm{HNO}_{3}$ and $\mathrm{HCl}$ were subject to microwave dissolving with applying of microwave mineralisator of firm Milestone. In such prepared samples determinations of iron content were made by means of above mentioned spectrometer of atomic absorption SOLAAR M6.

\section{Results and discussion}

Iron compounds present in natural waters in main measure originate from washing out rocks and soils. Greater amounts of this element originate from anthropogenic sources, among which the largest importance is played by mining waters and sewage coming from metallurgical plants (Hermanowicz et al. 1999). In result of coal burning iron also gets in atmosphere, from where, together with precipitation and also in result of dry deposition, it lands in surface waters (Dojlido 1995). Fine-grained and colloid iron hydroxides in considerable part undergo sorption by mineral and organic particles as well. These compounds in water of $\mathrm{pH}$ reaction below 7 undergo relatively easy dissolving. But at the access to oxygen, usually at surficial water layers, they oxidize and undergo precipitation in a form of different oxides (Kabata-Pendias and Pendias 1993). Iron concentrations observed in pure waters usually are shaped at the level of a tenth and a hundredth of $\mathrm{mg} \mathrm{l}^{-1}$, and in exceptional situations they reach the value of some $\mathrm{mg}$ $1^{-1}$ (Dojlido 1995).

Investigations carried out and results obtained confirmed the varied influence of anthropopression on concentration of iron compounds in described reservoirs. It refers to waters and bottom deposits as well (Table 1 and Fig. 2). Disproportions between particular reservoirs were stated, and changes within wide

Table 1. Minimum, average and maximum concentrations of iron $\left[\mathrm{mg} \mathrm{l}^{-1}\right]$ in water of the research reservoirs

\begin{tabular}{|c|c|c|c|c|c|c|c|c|c|}
\hline \multirow{2}{*}{ Location reservoirs } & \multicolumn{3}{|c|}{2003} & \multicolumn{3}{|c|}{2004} & \multicolumn{3}{|c|}{2005} \\
\hline & $\min$ & average & $\max$ & $\min$ & average & $\max$ & $\min$ & average & $\max$ \\
\hline Sosnowiec - No 1 & 0.0243 & 0.0713 & 0.2109 & 0.0043 & 0.0389 & 0.1026 & 0.0024 & 0.0233 & 0.0716 \\
\hline Sosnowiec - No 2 & 0.0436 & 0.1597 & 0.2895 & 0.0049 & 0.0777 & 0.4008 & 0.0121 & 0.0457 & 0.2052 \\
\hline Sosnowiec - No 3 & 0.0596 & 0.1678 & 0.3019 & 0.0023 & 0.0808 & 0.5950 & 0.0027 & 0.0843 & 0.5122 \\
\hline Sosnowiec - No 4 & 0.0122 & 0.1613 & 0.5954 & 0.0000 & 0.0753 & 0.2730 & 0.0010 & 0.0415 & 0.1215 \\
\hline „Żabie Doły” - No 5 & 0.0241 & 0.1092 & 0.2287 & 0.0000 & 0.0413 & 0.1700 & 0.0000 & 0.0207 & 0.0761 \\
\hline „Żabie Doły” - No 6 & 0.0070 & 0.0558 & 0.1392 & 0.0062 & 0.0305 & 0.0580 & 0.0000 & 0.0113 & 0.0350 \\
\hline „Żabie Doły” - No 7 & 0.0000 & 0.0345 & 0.0916 & 0.0000 & 0.0256 & 0.0564 & 0.0000 & 0.0175 & 0.1132 \\
\hline Zabrze - No 8 & 0.0144 & 0.1981 & 0.6255 & 0.0013 & 0.0426 & 0.2006 & 0.0000 & 0.0738 & 0.2425 \\
\hline Zabrze - No 9 & 0.0125 & 0.2537 & 0.4567 & 0.0000 & 0.0910 & 0.1869 & 0.0000 & 0.0620 & 0.2497 \\
\hline Zabrze - No 10 & 0.1590 & 0.4014 & 1.0825 & 0.0322 & 0.2019 & 0.3824 & 0.1184 & 0.7454 & 1.3744 \\
\hline
\end{tabular}




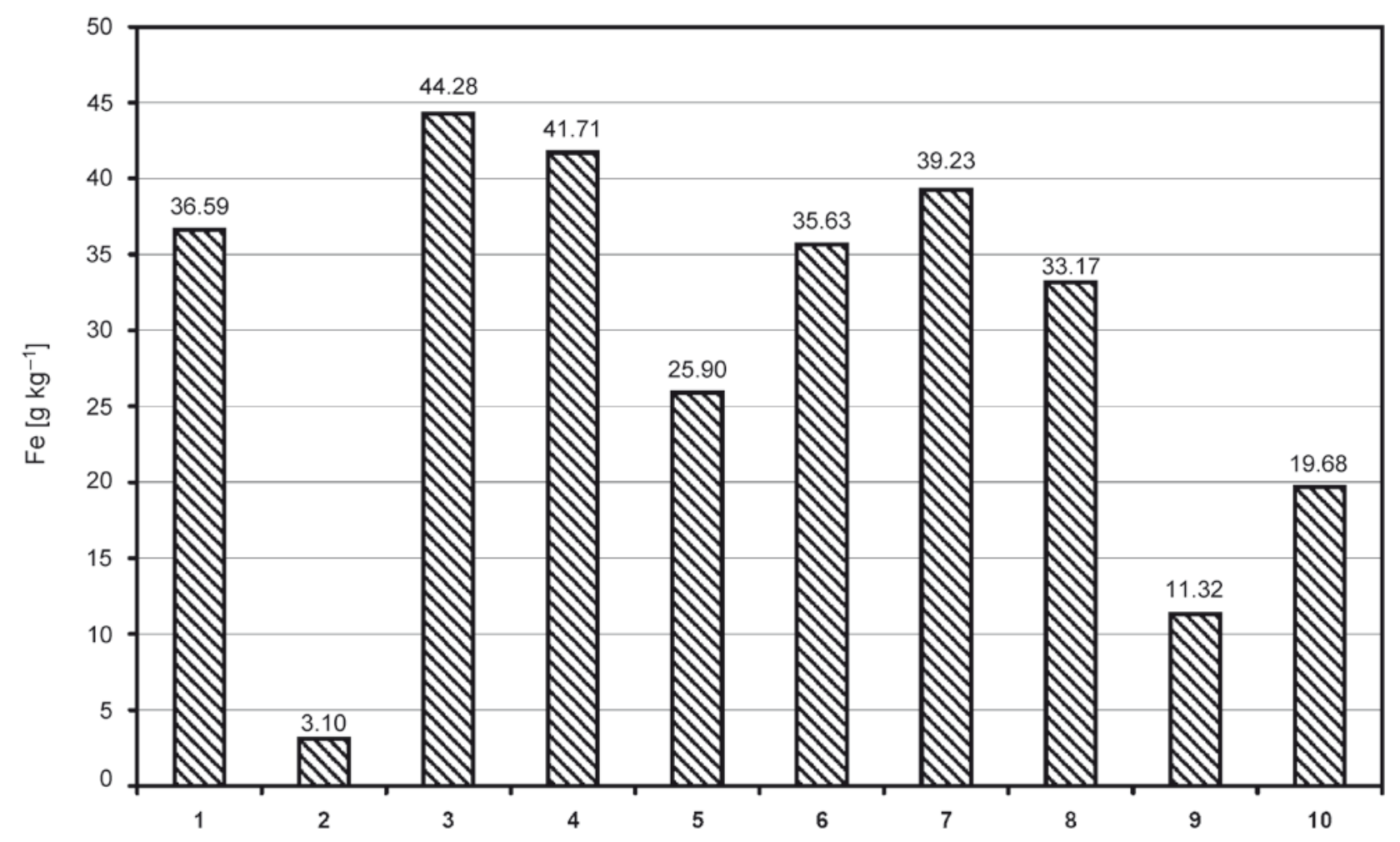

Fig. 2. The average concentration of iron $\left[\mathrm{g} \mathrm{kg}^{-1}\right]$ in bottom deposits of the research reservoirs

range in the following years of investigations were noted. The lowest average value $\left(0.0257 \mathrm{mg} \mathrm{Fe}^{-1}\right)$ for the period 2003-2005 was characteristic of reservoir No 7, which is located within the borders of the Natural-Landscape Complex „Żabie Doły”, whereas the maximum average concentration was a dozen or so times higher than the minimal value and it amounted to $0.4331 \mathrm{mg} \mathrm{Fe} \mathrm{l}^{-1}$, and it referred to reservoir No 10 located in Zabrze (Table 1). Functioning of described water reservoirs under the varied anthropopression translates into decidedly different concentration level of iron compounds in stored waters. To the total number of 348 measurements in six reservoirs (No 4-9) 12 cases occurred, when the investigated metal was not stated in waters. In other three reservoirs (No 1-3) minimum concentrations of iron were shaped on the level of a thousandth of milligram. But in waters of reservoir No 10 minimal iron concentrations occurred in slightly higher amounts. Seasonal complete disappearance of iron in limnic waters is also observed in lakes located in terrain of northern Poland (Tandyrak and Lizuraj 2008), and also in many lakes in the world (Inaba et al. 1997; Shaked et al. 2004; Cou- ture et al. 2010). The disappearance of iron in waters is most often correlated with phosphorus cycle in the water environment. Both elements rather easily react with each other, and then they undergo precipitation in a form of iron phosphate and sedimentation in bottom deposits (Kowalczewska-Madura et al. 2008; Grochowska and Tandyrak 2009).

Observed maximum concentrations of iron compounds in waters investigated changed from $0.1132 \mathrm{mg} \mathrm{Fe}^{-1}$ in October 2005 year in reservoir No 7 up to $1.3744 \mathrm{mg} \mathrm{Fe} \mathrm{l}^{-1}$ in June 2005 year in reservoir No 10 located in Zabrze (Table 1). Maximum values of iron measured in waters at particular research seasons remained on an approximated level, usually more than $0.1 \mathrm{mg} \mathrm{Fe}^{-1}$ with appearing certain separate features between particular objects (Table 1). Deviations from this rule were observed in reservoirs as follows: No 1 in Sosnowiec and No 5, 6 and 7 in the borderland of Bytom and Chorzów, where in particular years maxima were shaped only on the level of a hundredth of milligram (Table 1). Exceptional on that score was reservoir No 10 from Zabrze, in which in years 2003 and 2005 the metal investigated was noted 
two times in amount more than $1.0 \mathrm{mg} \mathrm{Fe}^{-1}$ (Table 1). Despite anthropopression influence on the water environment of the investigated reservoirs, results obtained do not stray from maximum values typical for lakes in northern Poland (e.g. Tandyrak and Lizuraj 2008; Grochowska and Tandyrak 2009). It also refers to lakes filling natural bowls located on particular continents of northern temperate climatic zone and also in objects located in northern hemisphere (Inaba et al. 1997; Zaw and Chiswell 1999; Couture et al. 2010). Slightly higher values, sporadically exceeding $1.0 \mathrm{mg} \mathrm{Fe} \mathrm{1}^{-1}$, were observed in the selected lakes only after torrential rains (Zaw and Chiswell 1999). This phenomenon is most likely connected with the iron compounds supply to the lake in wet form of their deposition from the atmosphere, as well as they can be washed down from the catchment surface (Jaguś and Rzętała 2003).

Among reservoirs investigated in waters, in which during the whole research period iron compounds occurred, the largest seasonal differences refer to the reservoir No 3. Measured in August of 2004 year

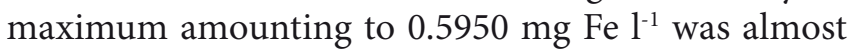
259 times higher than minimum iron content $(0.0023$ mg Fe $\mathrm{l}^{-1}$ ), which occurred in April of 2004 year (Table 1 ). This phenomenon results directly from the transfer (flow-through) character of reservoir. It is supplied by the Bobrek River, which makes the main receiver of mining waters originating from the black coal mine „Kazimierz-Juliusz”. In the remaining reservoirs extrema were significantly less varied and the minimum iron concentrations were from 40 up to nearly 90 times less than maximum values (Table 1). The largest iron amounts during the whole research period occurred in waters of reservoir No 10, because during the half of this period iron concentrations did not drop below $0.3106 \mathrm{mg} \mathrm{Fe}^{-1}$. In the remaining reservoirs the value of median changed from $0.0121 \mathrm{mg} \mathrm{Fe}^{-1}$ in res-

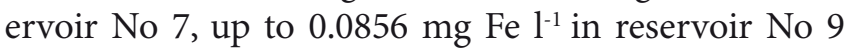
located in Zabrze.

Research on bottom deposits from the point of view of the presence of iron revealed also large differences between particular reservoirs. Averaged values proved, that especially low level of this metal concentration in amount of $3.1 \mathrm{~g} \mathrm{~kg}^{-1}$ occurred in transfer (flow-through) water reservoir No 2 located in Sosnowiec. Such low iron concentration can be connected with periodical washing out the finest fractions of deposits during raised water stages of the Bobrek, which flows through this reservoir, and thus the allocation of described metal. Slightly more than 3.5-times larger amounts of iron were accumulated in reservoir No 9, whereas the remaining reservoirs were characterized by decidedly larger values (Fig. 2). Among all investigated objects maximum values were characteristic of water reservoir No 3, which was located in Sosnowiec, and level of iron concentration in its deposits amounted to $44.28 \mathrm{~g} \mathrm{~kg}^{-1}$. Slightly lower iron concentrations in amount of $41.71 \mathrm{~g} \mathrm{~kg}^{-1}$ were measured in reservoir No 4 , which is also located in Sosnowiec and in reservoir No 7, situated in the central part of the Katowice Upland (Fig. 2).

The concentration level of iron compounds in bottom deposits of water reservoirs in subsidence depressions is rather considerably varied. But in any of them the level of geochemical background, given by A. Kabata-Pędias and H. Pendias (1993) and referring to all kinds of sedimentary rocks, was not exceeded. Data collected betoken varied influence of anthropopressions on the environment of standing waters of the Katowice Upland. The origination of iron compounds in bottom deposits of described water reservoirs is mainly connected with their outwashing and washing away from the catchment substratum. Of special significance in this respect is erosion of devoid of vegetation post-mining and post-metallurgical dumps and tips. Similar dependences occur in a case of lakes functioning in post-mining landscape of Lusatia in eastern Germany at the border with Poland (Kleeberg et al. 2008). Comparing obtained results with the concentration level of iron compounds in bottom deposits of other reservoirs forming the Upper Silesian Anthropogenic Lakeland one should state, that the measured values generally correlate with each other. Admittedly, reservoirs which are more loaded by this metal, function also in this area. Among them post-exploitation reservoirs Pogoria I. Pogoria II and dike reservoir Łężczok are numbered, in deposits of which iron compounds occurred in amount slightly more than $60 \mathrm{~g} \mathrm{~kg}^{-1}$ (Rzętała 2008), but these amounts are only insignificantly higher. On the other hand, in anthropogenic dike reservoirs located in the Czech Republic, iron occurred in amounts from about 30 up to about $40 \mathrm{~g} \mathrm{~kg}^{-1}$. Changeability of a similar scale was characteristic of bottom deposits of Irkutsk reservoir, lake on Olkhon Island on Baikal and fluvial lake in the valley of the Ob river (Rzętała 2008). 


\section{Recapitulation}

The concentration level of iron compounds in bottom deposits and waters of reservoirs in subsidence basins located in the Katowice Upland is shaped by varied influence of anthropopression. Therefore, between particular reservoirs essential disproportions occur with regard to iron compounds in water and in bottom deposits as well. Despite essential separate features, in majority of investigated water reservoirs the described metal occurs in amounts, which are characteristic of geosystems of quasi-natural features, devoid of the influence of strong anthropopression. Only in the case of one reservoir located in Zabrze slightly higher level of iron concentration was stated and it was observed only in its waters. It surely results from releasing of this element from bottom deposits in consequence of lowered $\mathrm{pH}$-reaction of stored waters. On the basis of carried out research it is possible to suppose, that local environmental conditions generally decide of spatial and temporal iron cycle in water reservoirs investigated. It is also confirmed by data referred to selected anthropogenic and natural lakes in Poland and in the world as well. Investigations carried out and results obtained betoken ecological changes, which occur in the neighbourhood of described water reservoirs treated as geosystems.

\section{References}

Burchard J., Hereźniak-Ciotowa U., Kaca W., 1990, Metody badań i ocena jakości wód powierzchniowych i podziemnych (Methods research and asses quality of surface and groundwater), Wyd. UŁ, Łódź, p. 250 (in Polish).

Couture R.M., Gobeil C., Tessier A., 2010, Arsenic. iron and sulfur co-diagenesis in lake sediments, Geochim. Cosmochim. Ac.74: 1238-1255.

Czaja S., 2003, Zbiorniki i pojezierza antropogeniczne (Reservoirs and anthropogenic lake district), [in:] T. Szczypek, M. Rzętała (eds) Człowiek i Woda (Man and Water), PTG Oddział Katowicki, Sosnowiec: 22-30 (in Polish).

Dojlido J., 1995, Chemia wód powierzchniowych (Chemistry of surface waters), Wyd. Ekonomia i Środowisko, Białystok, p. 344 (in Polish).

Dojlido J., Zerbe J., 1997, Instrumentalne metody badania wody i ścieków (Instrumental methods of examination of water and wastewater), Wyd. Arkady, Warszawa, p. 274 (in Polish).

Grochowska J., Tandyrak R., 2009, The influence of the use of land on the content of calcium. magnesium. iron and manganese in water, exemplified in three lakes in the Olsztyn vicinity, Limnol. Rev. 9(1): 9-16.
Hermanowicz W., Dojlido J., Dożańska W., Koziorowski B., Zerbe J., 1999, Fizyczno-chemiczne badanie wody i ścieków (Physico-chemical examination of water and wastewater), Wyd. Arkady, Warszawa, p. 556 (in Polish).

Inaba K., Sekine T., Tomioka N., Yagi A., 1997, Seasonal and longitudinal changes in copper and iron in surface water of shallow eutrophic lake Kasumigaura, Japan, Water Res. 31(2): 280-286.

Jaguś A., Rzętała M., 2003, Zbiornik Kozłowa Góra. Funkcjonowanie i ochrona na tle charakterystyki geograficznej i limnologicznej (Kozłowa Góra water reservoirs. Functioning and protection against a background of geographical and limnological charakteristics), PTG, Warszawa, p. 156 (in Polish).

Jankowski A. T., 1986, Antropogeniczne zmiany stosunków wodnych na obszarze uprzemysłowionym i urbanizowanym - na przykładzie Rybnickiego Okręgu Węglowego (Anthropogenic changes in water relations in the industrialized and urbanized area - the example of the Rybnik Coal District), Wyd. UŚ, Katowice. p. 280 (in Polish).

Jankowski A. T., Molenda T., Rzętała M., 2001, Reservoirs in subsidence basins and depression hollows in the Silesian Upland - selected hydrological matters, Limnol. Rev. 1: 143-150.

Jankowski A. T., Rzętała M., 2004, Stan badań limnologicznych $\mathrm{w}$ regionie górnośląskim (Status of limnological research in the Upper Silesia Region), [in:] A. T. Jankowski, M. Rzętała (eds) Jeziora i sztuczne zbiorniki wodne - funkcjonowanie. rewitalizacja i ochrona (Lakes and artificial reservoirs - the functioning. revitalization and protection), Wyd. UŚ - PTLim. - PTG, Sosnowiec: 101115 (in Polish).

Kabata-Pendias A., Pendias H., 1993, Biogeochemia pierwiastków śladowych (Biogeochemistry of trace elements), PWN, Warszawa, p. 364 (in Polish).

Kleeberg A., Schapp A., Biemelt D., 2008, Phosphorus and iron erosion from non-vegetated sites in a post-mining landscape, Lusatia, Germany: Impact on aborning mining lakes, Catena 72: 315-324.

Kowalczewska-Madura K., Dondajewska R., Gołdyn R., 2008, Influence of iron treatment on phosphorus internal loading from bottom sediments of the restored lake, Limnol. Rev. 8(4): 177-182.

Machowski R., Ruman M., Rzętała M., 2006, Silesian Upland as an anthropogenic lakeland, [in:] O. Rahmonov, M. A. Rzętała (eds) Anthropogenic aspects of landscape transformations, University of Silesia Faculty of Earth Sciences - Landscape Parks Group of the Silesian Voivodeship, Sosnowiec - Będzin: 55-61.

Machowski R., Rzętała M., 2006, Wyżyna Śląska i jej obrzeżenie jako „pojezierze antropogeniczne” (Silesian Upland and the margin of a ,anthropogenic lake district”), Wszechświat 107(1-3): 45-50 (in Polish).

Migaszewski Z. M., 1998, Metodyka badań geochemicznych gleb i biowskaźników roślinnych (Methods of geochemical soil and plant bio-indicators), Prz. Geol. 46(2): 159-163 (in Polish). 
Rzętała M., 2008, Funkcjonowanie zbiorników wodnych oraz przebieg procesów limnicznych w warunkach zróżnicowanej antropopresji na przykładzie regionu górnośląskiego (Functioning of water reservoirs and the course of limnic processes under conditions of varied antropopression a case study of Upper Silesian Region), Wyd. UŚ, Katowice, p. 172 (in Polish. English summary).

Shaked Y., Erel Y., Sukenik A., 2004, The biogeochemical cycle of iron and associated elements in Lake Kinneret, Geochim. Cosmochim. Ac. 68(7): 1439-1451.

Szpetkowski S., 1980, Charakterystyka wpływów robót górniczych na górotwór i na powierzchnię terenu (Characteristics of impacts of mining on the rock mass and on the ground surface), [in:] Ochrona powierzchni przed szkodami górniczymi (Surface protection against mining damage), Wyd. „Śląsk”, Katowice: 39-77 (in Polish).
Świderską-Bróż M., 1993, Mikrozanieczyszczenia w środowisku wodnym (Micropollutants in the aquatic environment), Wyd. PWr., Wrocław, p. 144 (in Polish).

Tandyrak R., Lizuraj M., 2008, Multiannual observations of iron and sulphur content in the waters of recultivated Lake Starodworskie. with comparision to selected physical and chemical parameters, Limnol. Rev. 8(3): 129-136.

Zaw M., Chiswell B., 1999, Iron and manganese dynamics in lake water, Water Res. 33(8): 1900-1910.

Żmuda S., 1973, Antropogeniczne przeobrażenia środowiska przyrodniczego konurbacji górnośląskiej (Anthropogenic changes of the Upper Silesian conurbation environment), Śl. Inst. Nauk., Katowice, p. 211 (in Polish). 